\title{
Modeling of seawater intrusion in a coastal aquifer of Karaburun Peninsula, western Turkey
}

\author{
Ahmed Y. S. Mansour ${ }^{1} \cdot$ Alper Baba $^{1} \cdot$ Orhan Gunduz $^{2} \cdot$ Celalettin Şimşek $^{2} \cdot$ Alper Elçii $^{2} \cdot$ Alim Murathan $^{3}$. \\ Hasan Sözbilir
}

Received: 19 December 2016 / Accepted: 13 November 2017 / Published online: 18 November 2017

○) Springer-Verlag GmbH Germany, part of Springer Nature 2017

\begin{abstract}
Seawater intrusion is a major problem to freshwater resources especially in coastal areas where fresh groundwater is surrounded and could be easily influenced by seawater. This study presents the development of a conceptual and numerical model for the coastal aquifer of Karareis region (Karaburun Peninsula) in the western part of Turkey. The study also presents the interpretation and the analysis of the time series data of groundwater levels recorded by data loggers. The SEAWAT model is used in this study to solve the density-dependent flow field and seawater intrusion in the coastal aquifer that is under excessive pumping particularly during summer months. The model was calibrated using the average values of a 1-year dataset and further verified by the average values of another year. Five potential scenarios were analyzed to understand the effects of pumping and climate change on groundwater levels and the extent of seawater intrusion in the next 10 years. The result of the analysis demonstrated high levels of electrical conductivity and chloride along the coastal part of the study area. As a result of the numerical model, seawater intrusion is simulated to move about $420 \mathrm{~m}$ toward the land in the next 10 years under "increased pumping" scenario, while a slight change in water level and TDS concentrations was observed in "climate change" scenario. Results also revealed that a reduction in the pumping rate from Karareis wells will be necessary to protect fresh groundwater from contamination by seawater.
\end{abstract}

Keywords Seawater intrusion · Density-dependent flow $\cdot$ SEAWAT $\cdot$ Karaburun $\cdot$ Turkey

\section{Introduction}

Seawater intrusion is among the main sources of groundwater contamination in coastal aquifers where saline water displaces or mixes with freshwater (Bear et al. 1999; Todd and Mays 2004). When the extraction of freshwater from a coastal aquifer exceeds the natural recharge of freshwater from rainfall or leakage from stream, brackish water is drawn into the aquifer. Seawater intrusion is a common problem in many European and Mediterranean coastal aquifers. Especially over the last several decades, seawater intrusion

Alper Baba

alperbaba@iyte.edu.tr

1 Faculty of Engineering, Izmir Institute of Technology, 35430 Urla, Izmir, Turkey

2 Faculty of Engineering, Dokuz Eylul University, 35390 Buca, Izmir, Turkey

3 2nd Regional Directorate of State Hydraulic Works, 35100 Bornova, Izmir, Turkey has become a crucial issue in Italy, Greece and Turkey, and numerous researches on seawater intrusion in coastal aquifers were conducted and reported by different researchers. For example, Felisa et al. (2013) studied and modeled seawater intrusion existing along the Adriatic coast of EmiliaRomagna, Italy. Baba et al. (2016) monitored seawater intrusion in Karaburun Peninsula, western Turkey. Karahanoglu and Doyuran (2003) used finite element simulation of seawater intrusion into costal aquifer of Darica, northwestern Turkey. Kallioras et al. (2006) developed a conceptual model for the management of a coastal aquifer in northern Greece. Qahman and Larabi (2006) developed a 3-D model for the numerical assessment of seawater intrusion in Gaza, Palestine, by applying a variable-density groundwater flow model. Sherif et al. (2012) presented the simulation of seawater intrusion in the coastal aquifer of Wadi Ham, United Arab Emirates, and analyzed the outcomes of different pumping scenarios. Gopinath et al. (2016) developed a numerical model to investigate the seawater intrusion in Nagapattinam coastal aquifer of Tamilnadu, India. Lin et al. (2009) 
studied the variable-density groundwater flow and miscible salt transport to assess the extent of seawater intrusion in the Gulf coast aquifer Alabama, USA. Cobaner et al. (2012) developed a model to investigate the current condition of salinization by examining seawater intrusion in the SilifkeGoksu Deltaic plain, and to assess the effects of pumping quantity on the extend of seawater intrusion. Sarsak and Almasri (2013) studied seawater intrusion into the coastal aquifer in the Gaza Strip, Palestine. Allow (2011) simulated both a subsurface physical barrier and injection well salinity barrier in the Damsarkho (Latakia), Syria, coastal plain. Abd-Elhamid and Javadi (2011) presented a cost-effective method to control the seawater intrusion in a coastal aquifer by desalination of the abstracted water and then recharging it back to the aquifer. Additional case studies on seawater intrusion were also conducted in different parts of the world such as the works of Gaaloul et al. (2012), Surinaidu et al. (2015), Paniconi et al. (2001) and Werner et al. (2013). The common problem that motivated all of these studies was the mismanagement of the coastal aquifers and available groundwater resources that resulted in uncontrolled saltwater intrusion.

Based on the above premise, this paper discusses a numerical study of seawater intrusion in the coastal aquifer of Karareis region (Karaburun Peninsula), western Turkey, where groundwater is the only source of freshwater for domestic and agricultural uses. A three-dimensional numerical model based on SEAWAT platform was developed in this study to assess the extent and characteristics of seawater intrusion. The model parameters were determined from analysis of well soil logs, permeability tests and chemical analysis of water samples. The model was calibrated and then validated before it was used to predict the extent of seawater intrusion in 10 years after 2015 for five expected scenario conditions.

\section{Site description}

Karareis region is located in the extreme western end of Karaburun Peninsula which is located about $100 \mathrm{~km}$ to the west of the City of Izmir (Fig. 1). The study area covers an area of $2.34 \mathrm{~km}^{2}$ between $26^{\circ} 24^{\prime} 46^{\prime \prime}-26^{\circ} 26^{\prime} 22^{\prime \prime}$ longitudes and $38^{\circ} 28^{\prime} 32^{\prime \prime}-38^{\circ} 29^{\prime} 56^{\prime \prime}$ latitudes. The surface morphology of the study area is characterized by an alluvial plain with normal regression, and there is a seasonal stream that divides the area into two parts. The study area is surrounded by mountains from three sides, and the fourth side is occupied by the sea. The land cover of study area includes agricultural fields, grasslands and settlement areas (summer houses) which have been increasing rapidly since 1980s. The number of summer houses in the region is estimated to be around 750 . For these settlements, the only source of freshwater is groundwater extracted from the surficial aquifer.

The climatic conditions of the study area follow that of typical Mediterranean climate with hot/dry summers and mild/rainy winters. The mean annual temperature of the peninsula ranges from 15 to $20^{\circ} \mathrm{C}$. The average daily maximum and minimum temperatures range from 19 to $32^{\circ} \mathrm{C}$ and from 8 to $20^{\circ} \mathrm{C}$ in summer and winter seasons, respectively. Rainfall data are collected in Karaburun meteorological station located $40 \mathrm{~km}$ away from the study area, and the annual

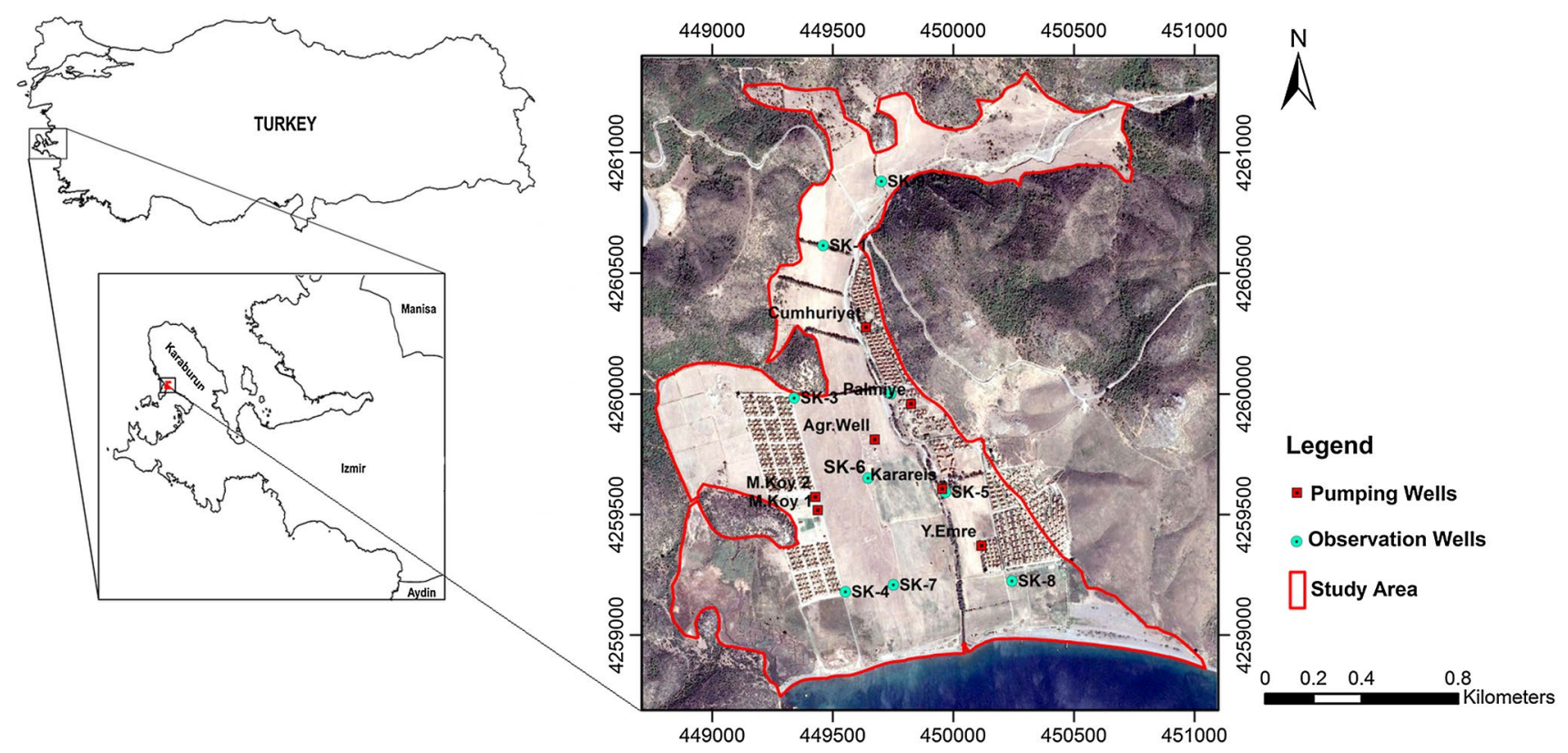

Fig. 1 Location map of the study area 
rainfall totals vary from $450 \mathrm{~mm}$ to $1200 \mathrm{~mm} /$ year during 1970-2016 periods.

\section{Materials and methods}

A comprehensive data collection effort was conducted in Karareis aquifer to characterize the geomorphology, geology, hydrology and hydrogeology of the system. Necessary information about the coastal aquifer and its environs were obtained from field studies and GIS-integrated assessments. A total of nine boreholes (SK-1 to SK-9) were drilled in the study area to determine the geological and hydrogeological setting of the coastal aquifer (see Fig. 1). Core samples obtained from these boreholes were used to estimate the physical and hydraulic properties of the aquifer. Boreholes were later converted to monitoring wells for water level measurement and water quality sampling. Groundwater level measurements were conducted using two methods. For SK-1, SK-2, SK-3, SK-4, SK-7 and SK-8 wells, automatic groundwater data loggers (Schlumberger Mini Diver) were installed to continuously monitor the water level fluctuations and groundwater physical parameters, and the remaining wells (SK-5, SK-6 and SK-9) were measured manually on pre-determined time intervals. The automatic data loggers recorded electrical conductivity, water level and temperature values every hour and stored them in its internal memory. The stored data were later downloaded from the data loggers and compensated for pressure fluctuations. The data loggers recorded groundwater physical parameters (temperature and conductivity) for the period July 2014-July 2015 . The manual measurement of temperature and electrical conductivity were done with multi-parameter probes (HACH-LANGE HQ40d). During field work, groundwater samples were also collected from the observation wells in three time periods during September 2014, April 2015 and September 2015 to characterize timely variations of quality parameters. In addition to several other parameters, all samples were analyzed for chloride to understand saltwater intrusion phenomena in the aquifer.

\section{Geological and hydrogeological properties of the region}

The Karaburun Peninsula is made up of The Early-Middle Carboniferous-Jurassic rocks of platform carbonates, Late Paleozoic-Early Triassic flysch-type (Karareis formation) and Upper Cretaceous to Paleocene rocks of Bornova Flysch Zone. The flysch-type metasediments crop out around the Karareis site. These metasediments are subdivided into a sequence of weakly deformed brown and gray phyllites, and a pack of highly deformed dark sericitic metapelites.
Generally, these units consist of limestone olistoliths around Karareis region. These units are not permeable, and they do not have any wells around Karareis region. They are unconformably overlain by coastal alluvial aquifer.

The topography of study area was determined by using $90 \mathrm{~m}$ resolution SRTM data (Jarvis et al. 2008). Accordingly, the land surface elevation of the study area ranges from mean sea level (MSL) to about $40 \mathrm{~m}$ above mean sea level. The maximum depth of monitoring wells was $56 \mathrm{~m}$, and the alluvial materials were found to range in the first $40 \mathrm{~m}$. Alluvial deposits extend to a maximum depth of $52 \mathrm{~m}$ below land surface within the study area. The alluvium mainly consists of a mixture of gravel, sand and sandy gravel, while the aquifer base is composed of flyschtype metasediments. The flysch unit has a small permeability value with an average of $4.6 \times 10^{-7} \mathrm{~m} / \mathrm{s}$ (Marinos et al. 2011).

The groundwater flow in the study area is mainly southward toward the Aegean Sea. The saturated thickness of the aquifer ranges from $52 \mathrm{~m}$ near the sea to $45 \mathrm{~m}$ near the northern aquifer boundary. Recharge from rainfall is considered to be the major source of groundwater renewal mechanism in the aquifer. Lateral groundwater flow was not significant in the area due to impervious layers surrounding the aquifer boundary. An overall view of the groundwater fluctuations in the surface aquifer of Karareis revealed that the groundwater level reached its lowest point in the beginning of July of 2014, and it was stable at that point until mid of December of 2014. Thereafter, infiltration of rainfall water caused a rise in groundwater levels between December 2014 and April 2015. A peak in groundwater level was monitored in mid of March 2015. Figure 2 shows the fluctuation of groundwater levels of the surficial aquifer for the period July 2014 to October 2015, which was a comparably high precipitation year.

\section{Numerical model}

SEAWAT (version 4) model is used to simulate the seawater intrusion into the coastal aquifer in Karareis region. The original code was released by Guo and Bennett (1998) and was applied by numerous researchers (Bakker 2003; Bakker et al. 2004; Langevin 2003; Dausman and Langevin 2005; Schneider and Kruse 2006; Zimmermann et al. 2006). SEAWAT combines MODFLOW (McDonald and Harbaugh 1988) and MT3DMS (Zheng and Wang 1999) into a single computer model for the purpose of simulating saltwater intrusion. The reader is referred to Langevin et al. (2008) for theoretical background of variable-density groundwater flow and its implementation in SEAWAT. 

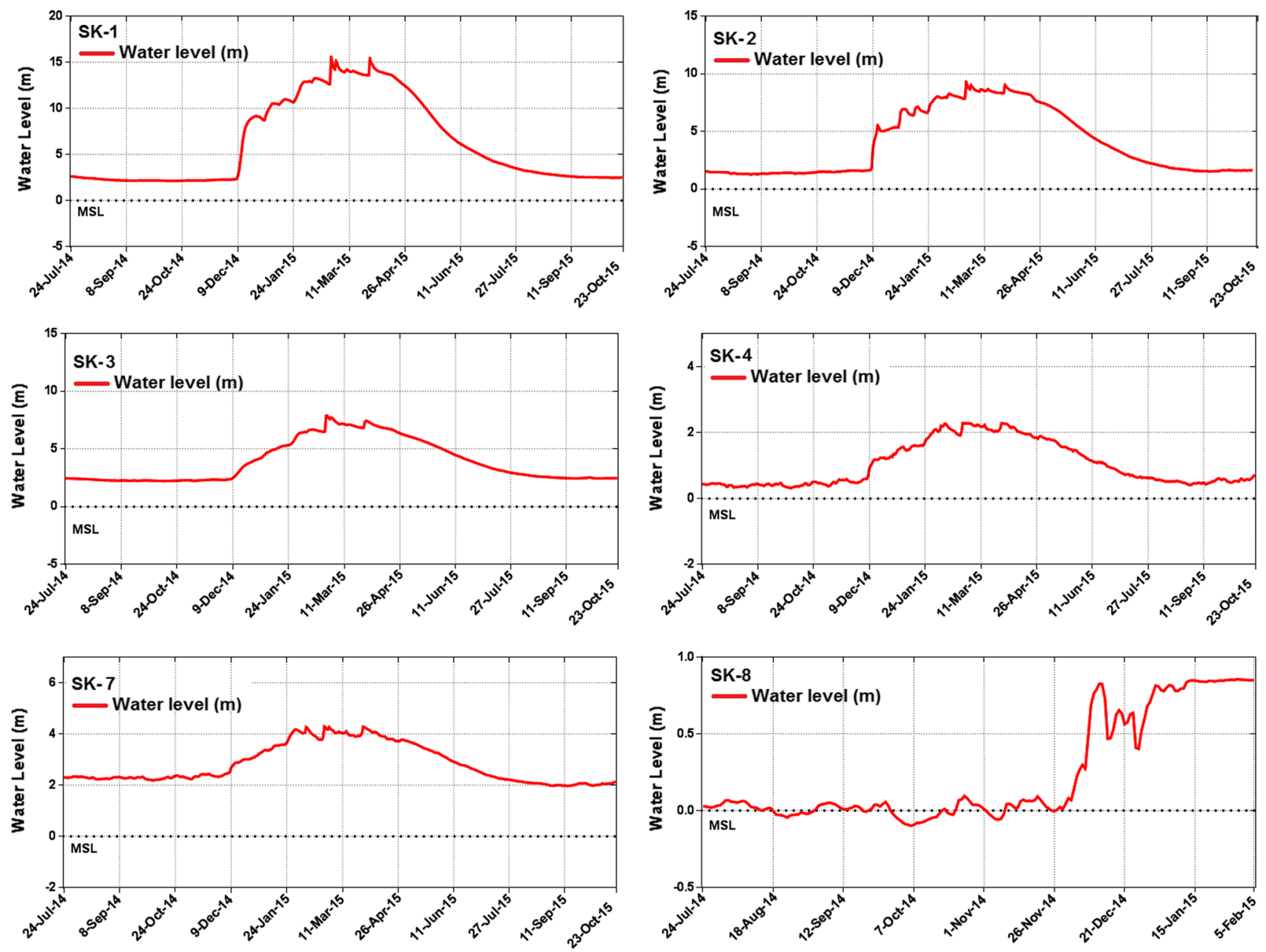

Fig. 2 Fluctuation of groundwater level measured in SK-1, 2, 3, 4, 7 and 8 for the period (2014-2015)

\section{Hydrogeological parameters}

The hydraulic conductivity values determined from laboratory tests are interpolated to give the initial distribution of conductivity (Fig. 3). The map reveals the high values of hydraulic conductivity in the alluvial units around the stream. The interpolation algorithm used, however, created a slight decline in the hydraulic conductivity distribution along the northern parts of the study area, which was mainly attributed to the lack of data points outside the modeling domain. The hydraulic conductivity was also assumed to be isotropic in the longitudinal direction and lateral directions and anisotropic in the vertical direction where hydraulic conductivity was taken to be $10 \%$ of the horizontal hydraulic conductivity (Kresic 2007).

Based on the results of the grain size distribution obtained from the core samples, approximately seventy percent of soil samples are classified as well-graded sand (SW) according to the uniformity coefficient which is greater than 6 and the rest can be classified as poorly graded sand (SP). The percentage of silt and clay in the samples was less than $5 \%$ except the core samples which were taken from the top 5 meters. The sieve analysis revealed that the majority of the samples collected from the study area are composed of coarse sand and fine gravel. Porosity for this type of sample ranges from 0.23 to 0.43 , and the value of specific yield ranges between 0.13 and 0.40 (Das 2013; Morris and Johnson 1967).

The values of the longitudinal and vertical transverse dispersivities are obtained from the published data by Qahman and Larabi (2006). The aquifer parameters used in simulations are listed in Table 1. In the model, the longitudinal dispersivities were estimated to be $25 \mathrm{~m}$ while the specific storativity was $1 \times 10^{-5} \mathrm{~m}^{-1}$ for the confined layers and specific yield for the unconfined layer $\mathrm{S}_{\mathrm{y}}$ was selected as 0.2. The effective porosity was assumed as 0.25 .

\section{Recharge}

Groundwater recharge consists of infiltration from precipitation, seepage flow from the seasonal stream and percolations 


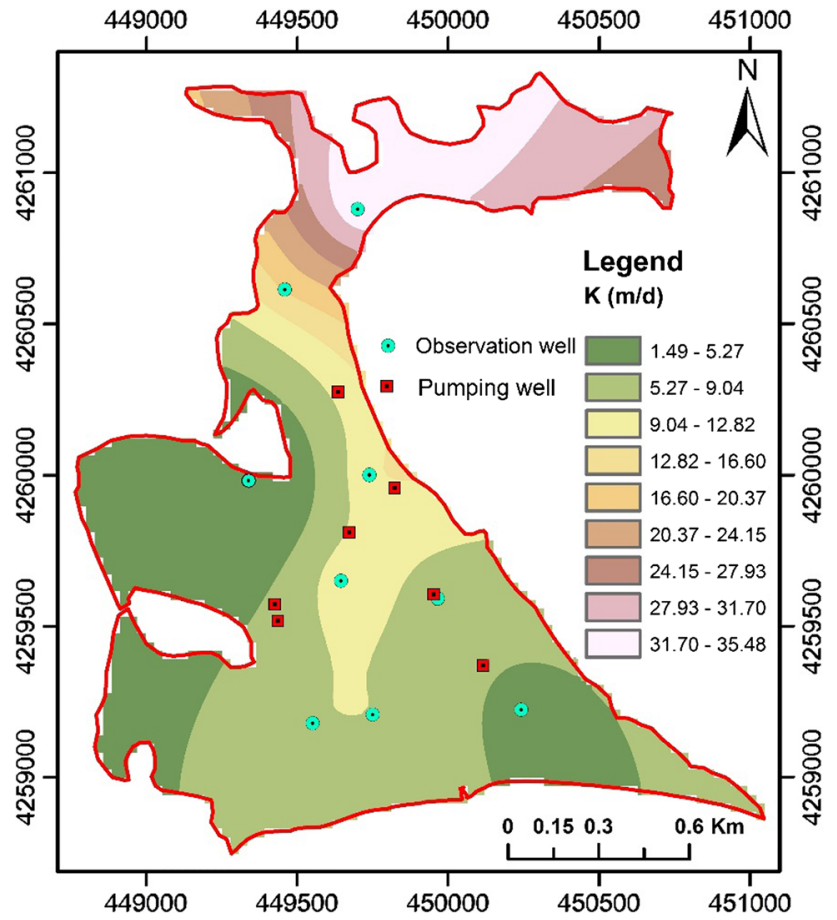

Fig. 3 Distribution of hydraulic conductivity in longitudinal direction $\mathrm{K}(\mathrm{m} / \mathrm{d})$

Table 1 Aquifer parameters assigned for alluvial aquifer of Karareis region

\begin{tabular}{lll}
\hline Parameter & Value & Unit \\
\hline Total porosity & 0.30 & \\
Effective porosity & 0.25 & \\
Specific yield & 0.20 & \\
Longitudinal dispersivity & 25 & $\mathrm{~m}$ \\
Transversal dispersivity & 0.25 & $\mathrm{~m}$ \\
Diffusion coefficient & 0.1 & $\mathrm{~m}^{2} / \mathrm{day}$ \\
Freshwater density & 1000 & $\mathrm{~kg} / \mathrm{m}^{3}$ \\
Seawater density & 1025 & $\mathrm{~kg} / \mathrm{m}^{3}$ \\
Seawater concentration & 35,000 & $\mathrm{mg} / \mathrm{L}$ \\
Density/concentration slope & 0.7143 & \\
TDS concentration of recharge & 0 & $\mathrm{mg} / \mathrm{L}$ \\
\hline
\end{tabular}

from irrigated area. The major portion of the recharge to groundwater is from the precipitation and the stream. This is reflected by the fact that the groundwater level in the aquifer rises continuously during the rainy season of the year. During the dry season, the groundwater levels falls depending on the discharge amount. The recharge is often used as a calibration parameter and varies along with the hydrogeological material properties. For the steady-state model, the recharge rate was estimated to be $320 \mathrm{~mm} /$ year, which was computed equivalent to $23.8 \%$ of the $1347 \mathrm{~mm}$ total precipitation for the modeling period (July 2014-August 2015). As for the transient model, due to lack of daily recharge data, daily recharge rates are assigned based on daily precipitation data assuming that recharge is proportional to precipitation. Consequently, the yearly total amount of recharge was the same as in the steady-state model $(320 \mathrm{~mm} /$ year $)$.

\section{Estimation of groundwater extraction}

In Karareis region, there are six legal pumping wells that satisfy the domestic needs of the summer houses, and one agricultural well that is used for irrigation. The pumping rates of these wells for the two periods (summer and winter) are listed in Table 2. The total amount of water used by each summer house for domestic consumption was about $1.3 \mathrm{~m}^{3} /$ day; however, the actual groundwater pumped from the aquifer is greater than the estimated, due to a number of illegal pumping wells. Agriculture, on the other hand, is considered to be the major water consumer, with typical water use value of about $120 \mathrm{~m}^{3} /$ day over the year. The daily pumping rates in the transient model were assumed to be constant for each season.

\section{Model discretization and boundary conditions}

A finite difference grid has been used to discretize the study area by dividing into 100 rows and 100 columns for one layer (Fig. 4), resulting in a constant cell size of $23 \mathrm{~m}$. The northern, eastern and western boundaries are assumed to be no-flow boundaries. Constant head and constant concentration boundary conditions were specified to the model cells along the coast. The constant seawater head and concentration of total dissolved solid were taken to be $0 \mathrm{~m}$ and $35,000 \mathrm{mg} / \mathrm{L}$, respectively. However, the exact position of this boundary is not known due to the scarcity and uncertainty of data (Fig. 4). Three stress periods were defined in the transient model which ended after 1, 5 and 10 years. Daily time steps were used for the entire simulation.

\section{Initial conditions}

The initial head and concentration boundary conditions are set at the beginning of the simulation period in order to start solving the flow equations. MODFLOW needs an initial "guess" for the head values in the model. A good initial head guess for the simulation reduces the required run time significantly in the transient state. Within the study area, the initial water levels were set to zero elevation from the mean sea level. The initial concentration was calculated by interpolating the concentration of total dissolved solids from the monitoring wells along the model domain. The results of the steady-state run were used as initial conditions for transient simulation of seawater intrusion. 
Table 2 Rate of water pumping in winter and summer period

\begin{tabular}{|c|c|c|c|c|c|c|}
\hline \multirow[t]{2}{*}{ Well ID } & \multirow[b]{2}{*}{ No. $\mathrm{SH}^{\mathrm{a}}$} & \multicolumn{2}{|l|}{ Summer } & \multicolumn{2}{|l|}{ Winter } & \multirow{2}{*}{$\begin{array}{l}\text { Yearly average } \\
Q\left(\mathrm{~m}^{3} / \mathrm{d}\right)\end{array}$} \\
\hline & & No. SH & $\mathrm{Q}\left(\mathrm{m}^{3} / \mathrm{d}\right)$ & No. SH & $\mathrm{Q}\left(\mathrm{m}^{3} / \mathrm{d}\right)$ & \\
\hline Palmiye & 30 & 30 & 40 & 9 & 3 & 12 \\
\hline Cumhuriyet & 180 & 130 & 130 & 10 & 4 & 35 \\
\hline Karareis & 305 & 270 & 270 & 30 & 10 & 74 \\
\hline M.Koy 1 & 100 & 100 & 100 & 10 & 4 & 27 \\
\hline M.Koy 2 & 100 & 100 & 100 & 10 & 4 & 27 \\
\hline Y.Emre & 25 & 20 & 20 & 2 & 1 & 5 \\
\hline Agr.Well $^{\mathrm{b}}$ & - & 120 & & 120 & & 120 \\
\hline
\end{tabular}

${ }^{\mathrm{a}}$ Summerhouse, ${ }^{\mathrm{b}}$ Agricultural well
Fig. 4 Finite difference grid and boundary conditions for Karareis model

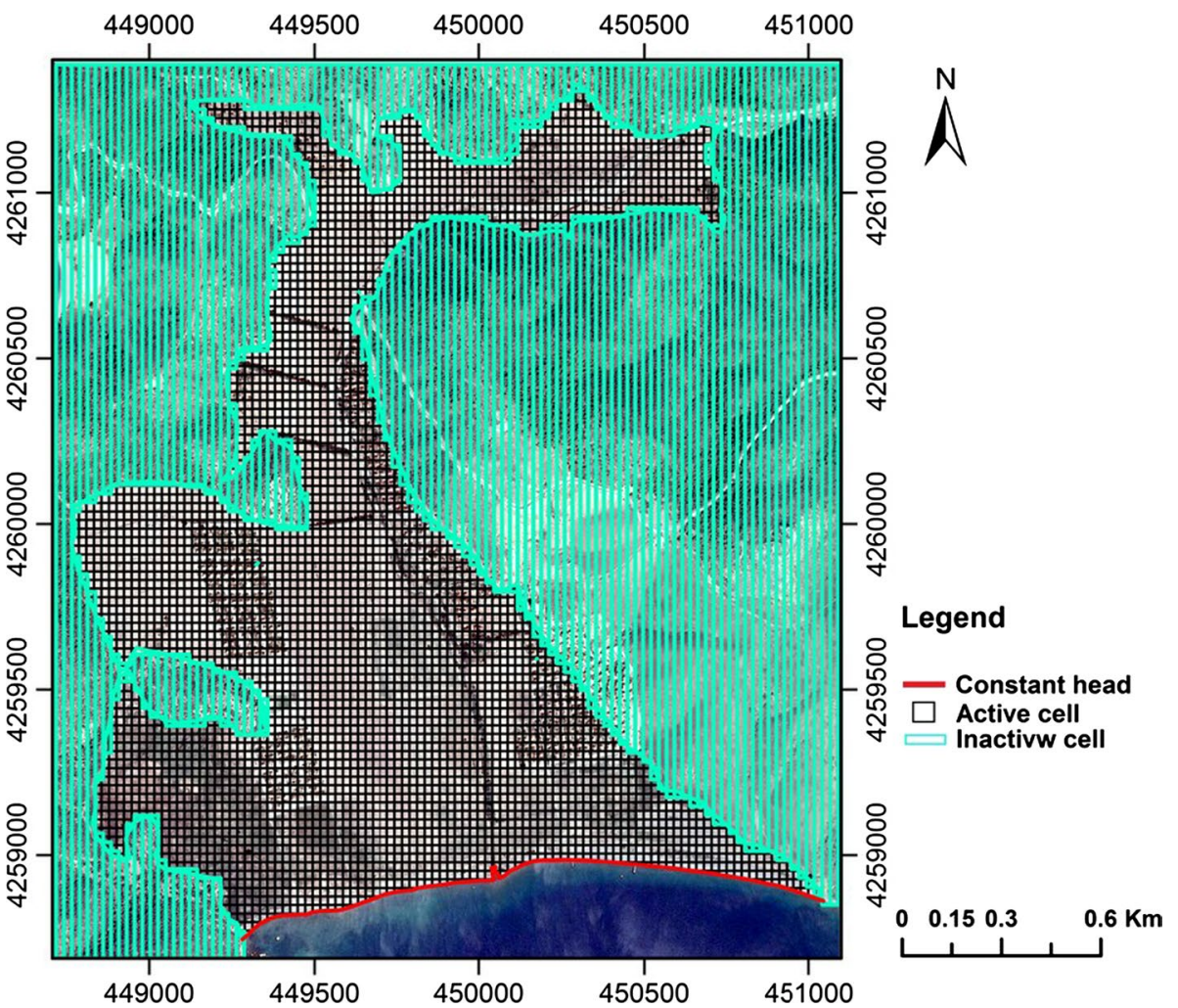

\section{Model calibration and validation}

Model calibration is achieved through nonlinear parameter estimation (PEST) approach by adjusting the values of hydraulic conductivity until the hydraulic head values calculated by MODFLOW match the observed values to a satisfactory degree. The model was run numerous times for various values of hydraulic conductivity distributions over the domain. Model calibration is stopped when a reasonable match between the calculated and observed heads is achieved. SEAWAT calibration was conducted for the (2014-2015) target period, using the calibrated (2014-2015) steady-state results as the initial conditions. Table 3 presents the residuals obtained between the observed and calculated heads. It also summarizes the fundamental statistics of SEAWAT calibration between observed and calculated heads. Figure 5a shows the calibrated and observed water heads. An overall of correlation coefficient of 0.95 and root-mean-squared error (RMSE) of $0.474 \mathrm{~m}$ were obtained which indicated a good match between the calculated and the observed heads.

For the solute transport part, TDS was used as the simulated parameter. During the calibration period, a total of nine observed TDS values were used in the period of 2014-2015. Model calibration was terminated when a reasonably good match between the observed and calculated concentrations was achieved. In the simulation, the correlation coefficient between the calculated and observed TDS values was obtained to be 0.89 , and the RMSE was calculated to be $350.6 \mathrm{mg} / \mathrm{L}$ (Fig. 5b). The fundamental statistics between 
Table 3 Observed and calculated heads and TDS concentration with residual of 9 observation wells

\begin{tabular}{|c|c|c|c|c|c|c|c|}
\hline Target well & $\begin{array}{l}\text { Screen } \\
\text { depth }(\mathrm{m})\end{array}$ & $\begin{array}{l}\text { Observed } \\
\text { head }(\mathrm{m})\end{array}$ & $\begin{array}{l}\text { Calculated } \\
\text { head }(m)\end{array}$ & Residual head (m) & $\begin{array}{l}\text { Observed } \\
\text { TDS (mg/L) }\end{array}$ & $\begin{array}{l}\text { Calculated } \\
\text { TDS (mg/L) }\end{array}$ & $\begin{array}{l}\text { Residual } \\
\text { concentration } \\
(\mathrm{mg} / \mathrm{L})\end{array}$ \\
\hline SK-1 & 40 & 7.15 & 7.37 & 0.22 & 725 & 789 & 64 \\
\hline SK-2 & 39 & 4.53 & 4.13 & -0.39 & 450 & 533 & 83 \\
\hline SK-3 & 34 & 4.22 & 4.35 & 0.12 & 1138 & 1037 & -101 \\
\hline SK-4 & 36 & 1.15 & 1.82 & 0.66 & 518 & 938 & 420 \\
\hline SK-5 & 44 & 2.62 & 2.53 & -0.08 & 1298 & 1245 & -54 \\
\hline SK-6 & 42 & 2.35 & 3.05 & 0.70 & 864 & 850 & -14 \\
\hline SK-7 & 52 & 2.25 & 1.74 & -0.51 & 4135 & 3198 & -937 \\
\hline SK-8 & 46 & 0.25 & 1.03 & 0.78 & 823 & 970 & 147 \\
\hline SK-9 & 46 & 8.23 & 8.14 & -0.09 & 1214 & 1131 & -83 \\
\hline Max. Residual & & & & 0.78 & & & 937 \\
\hline Min. Residual & & & & -0.08 & & & -14 \\
\hline Residual Mean & & & & 0.16 & & & -52.7 \\
\hline Abs. Residual Mean & & & & 0.39 & & & 211.3 \\
\hline Standard Error of the Estimate & & & & 0.16 & & & 122.54 \\
\hline Normalized RMS & & & & $5.94(\%)$ & & & $9.514(\%)$ \\
\hline
\end{tabular}

the calculated and observed TDS values are also listed in Table 3.

Following calibration, the model was validated by using the field observation data of the next year 2015-2016. The average of hydraulic head for the same observation wells was taken for validation of SEAWAT. The statistical analysis revealed that the correlation coefficient was 0.94 , and the RMSE was $1.207 \mathrm{~m}$ (Fig. 5c). The calculated values of model matched the field observed values. Therefore, no further refinement of the model was necessary and the model was considered to be ready for predictive simulations. Due to scarcity of the observed TDS concentrations and continuously monitored electrical conductivity data, the model is only validated against the observed heads at the end of the simulation.

\section{Results and discussions}

Current status of seawater intrusion was assessed. Here, electrical conductivity measurements are good indicators of salinity for a coastal aquifer. It is evident from Fig. 6 that there is a relationship between the electrical conductivity and precipitation in the study area. The change in the electrical conductivity of the water is mainly dependent on the amount of recharge from rainfall and periods of groundwater pumping, which can be correlated with the change in water level. The electrical conductivity reached highest levels in the driest (summer) period after which it started to fall and reached its lowest value during the rainy (winter) period. Based on the observations between July 2014 and September
2015, the electrical conductivity varied from 420 to $3797 \mu \mathrm{s} /$ $\mathrm{cm}$, except the borehole SK-7. The electrical conductivity reached its highest level in August 2014 and later started to fall progressively to reach its lowest level in April 2015 (Table 4). As shown in Table 5, water samples from SK-1 to SK-9 (excluding SK-7) were characterized with low chloride concentrations which ranged from 35 to $66 \mathrm{mg} / \mathrm{L}$. However, in SK-7, the chloride concentration exceeded $6000 \mathrm{mg} / \mathrm{L}$ in September 2015.

The monitoring and modeling results reveal that groundwater pumping from Karareis coastal aquifer increases significantly during the summer period to meet the agricultural and domestic water demands. Nine boreholes were drilled in the aquifer and groundwater levels were measured on a continuous basis at these locations. The borehole data also reveal that the thickness of the alluvial layer extends to a maximum depth of $52 \mathrm{~m}$ below land surface. This corresponds to a moderate thickness when the spatial extent of the aquifer was concerned. The thickness of the aquifer decreased with increasing distance from the shoreline. An overall assessment of groundwater fluctuations showed that the groundwater level reached its lowest point in dry summer season and after that, infiltration of rainfall caused a rise in groundwater level during wet season. A peak in groundwater level was monitored in mid-March during the analyzed time period.

The physical parameters of the water were measured regularly in the observation wells. As electrical conductivity measurements provide a good indication for salinity, a decline in the electrical conductivity of the water was mainly dependent on the amount of recharged water due to rainfall, 
Fig. 5 a Calculated versus observed hydraulic heads for calibration, b calculated versus observed TDS concentrations for calibration, c calculated versus observed heads for validation
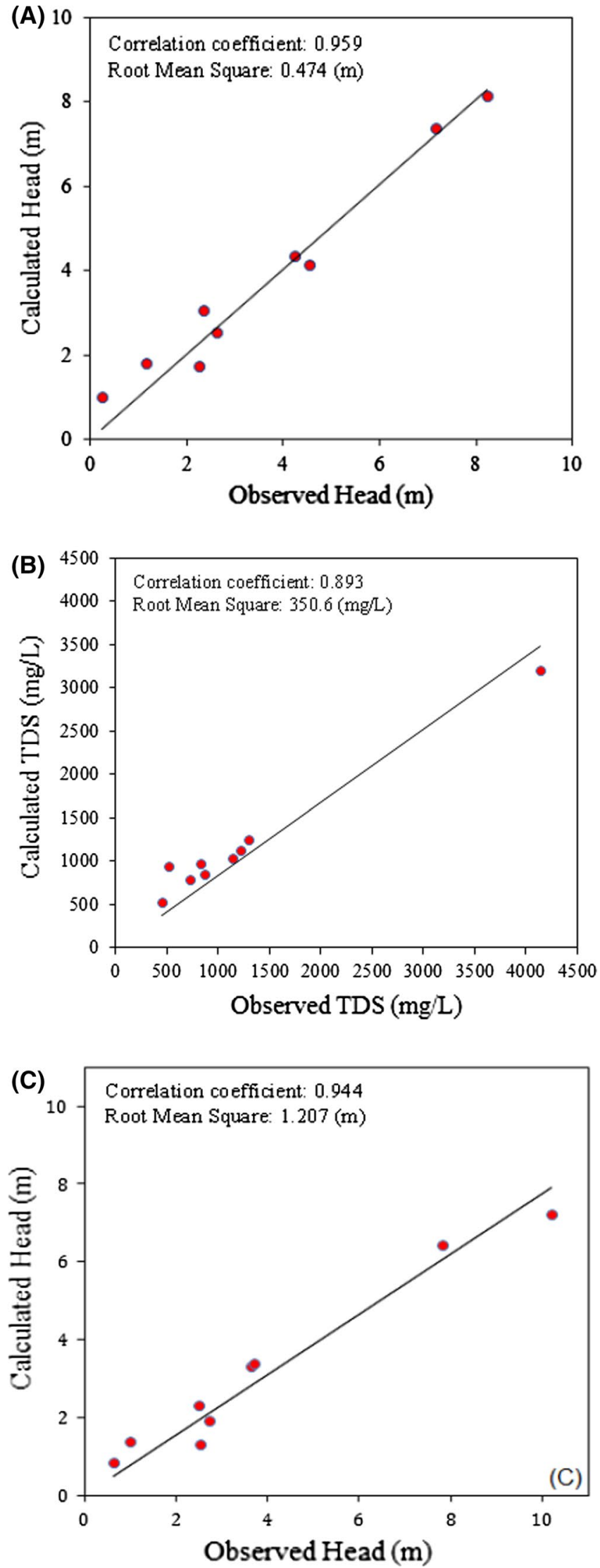

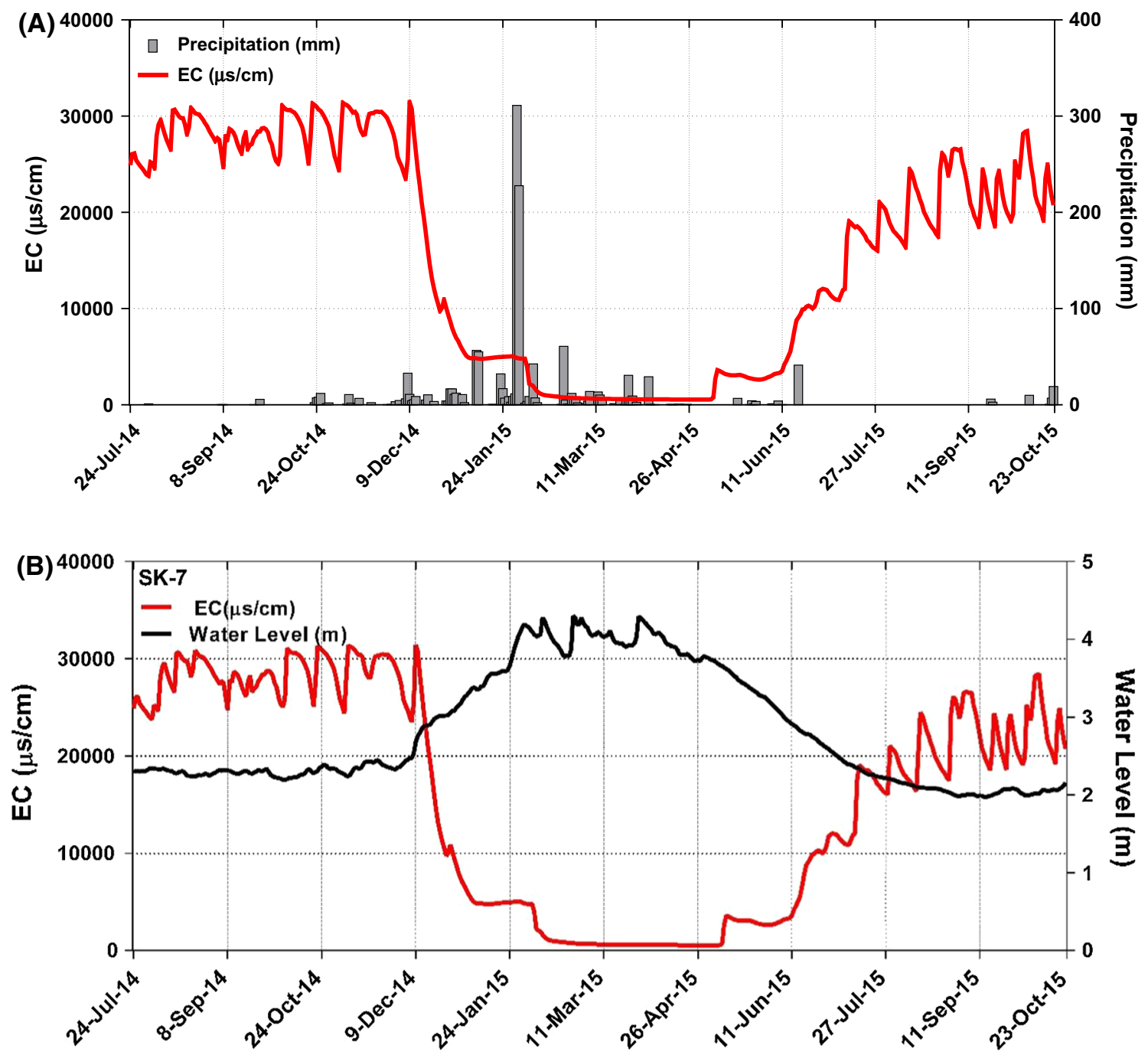

Fig. 6 a Fluctuations in electrical conductivity (EC) measured in SK-7 and daily precipitation recorded by Karaburun Meteorological Station. b Fluctuations in electrical conductivity (EC) and groundwater levels measured in SK-7

Table 4 Typical EC values ( $\mu$ s/ $\mathrm{cm}$ ) obtained by using portable meter

\begin{tabular}{lrrrrrrrrr}
\hline Date & \multicolumn{7}{l}{ Observation Well } & \multicolumn{1}{l}{} & \\
\cline { 2 - 9 } & SK-1 & SK-2 & SK-3 & SK-4 & SK-5 & SK-6 & SK-7 & SK-8 & SK-9 \\
\hline $7 / 23 / 2014$ & 704 & 485 & 1251 & 605 & 1549 & 750 & 7148 & 856 & 1513 \\
$8 / 22 / 2014$ & 1757 & 1222 & 3122 & 1485 & 3797 & 1812 & 16,060 & 2440 & 3690 \\
$9 / 18 / 2014$ & 581 & 420 & 2268 & 608 & 1382 & 2645 & 1315 & 865 & 2408 \\
$4 / 16 / 2015$ & 618 & 481 & 877 & 554 & 1730 & 579 & 626 & 932 & 453 \\
$6 / 12 / 2015$ & 1752 & 750 & 974 & 612 & 1231 & 662 & 5711 & 1045 & 997 \\
$9 / 02 / 2015$ & 1797 & 592 & 952 & 605 & 1009 & 610 & 20,765 & 1201 & 932 \\
\hline
\end{tabular}

which can also be indicated by the change in water level. The results revealed that electrical conductivity reached the highest level in the driest (summer) period after which it started to fall to reach its lowest value during the wet period in the study area (see Fig. 6). It's clearly seen that groundwater level and chemical properties of water were influenced from seawater intrusion in the observation wells. One of the main reasons of this intrusion was due to the increase in groundwater withdrawal of both agricultural activates and domestic use especially in dry period in the study area.

The variable-density groundwater flow model SEAWAT was used to simulate the seawater intrusion in the coastal 
Table 5 Concentration of chloride (mg/L) for the period (2014-2015)

\begin{tabular}{lllr}
\hline Observation well & Sep (2014) & Apr (2015) & Sep (2015) \\
\hline SK-1 & - & 44.17 & 234.47 \\
SK-2 & 41.8 & 33 & 35.76 \\
SK-3 & - & 62.14 & 66.17 \\
SK-4 & - & 41.79 & 42.96 \\
SK-5 & - & 49.03 & 46.39 \\
SK-6 & 109 & 46.3 & 40.61 \\
SK-7 & 2217 & 50.47 & 6709.56 \\
SK-8 & - & 37.81 & 38.92 \\
SK-9 & 63.7 & 36.28 & 37.97 \\
\hline
\end{tabular}

aquifer of Karareis. The simulation results of SEAWAT were exported to ArcGIS shape line format (ESRI Inc.) and the contour lines of the water head calculated by using MODFLOW for the period 2014-2015 are presented in Fig. 7. The salinity distribution represented as TDS (mg/L) at the end of the simulation period is presented in Fig. 8. As the figure reveals, the seawater intrusion near SK-7 extended about $500 \mathrm{~m}$ inland and the most affected area by seawater intrusion was located around this observation well. One of the main reasons of this intrusion was the increased water withdrawal from the agricultural well and the Karareis wells with average pumping being equal to 120 and $80 \mathrm{~m}^{3} /$ day, respectively (Fig. 8). The TDS concentrations at this location rose to approximately $3000 \mathrm{mg} / \mathrm{L}$, and later started to fall progressively to $1000 \mathrm{mg} / \mathrm{L}$ near
SK-6. Thus, excessive seasonal withdrawal of groundwater from wells near the coast was considered to be the main reason of seawater intrusion into Karareis surficial aquifer. In order to prevent further intrusion of seawater into the aquifer, groundwater withdrawal should be decreased near the coastline.

To demonstrate the effect of future changes in groundwater pumping and annual precipitation on seawater intrusion, five scenarios were developed. The calibrated model was used for calculations of future changes in water levels and TDS concentrations over the next 10 years (2014-2024). In all scenarios, the recharge rate was taken to be equal to that of the $2014-2015$ periods (i.e., $320 \mathrm{~mm} /$ year). The scenarios are presented as follows:

- Scenario 1: Baseline scenario-No change to occur in the study area

- Scenario 2: Perennial habitation-Annual pumping rate from the aquifer will be increased to the pumping rate in the summer season (none of the people leave summerhouses)

- Scenario 3: Increase in water demand-Pumping from the aquifer will be doubled in the same pumping wells

- Scenario 4 (worst-case scenario): Intensification of agricultural activity-Three new agricultural wells will be drilled with similar flow rates

- Scenario 5: Climate change effect-A $20 \%$ reduction in the annual precipitation rate occurs
Fig. 7 Simulated water level for the period (2014-2015) calculated by MODFLOW

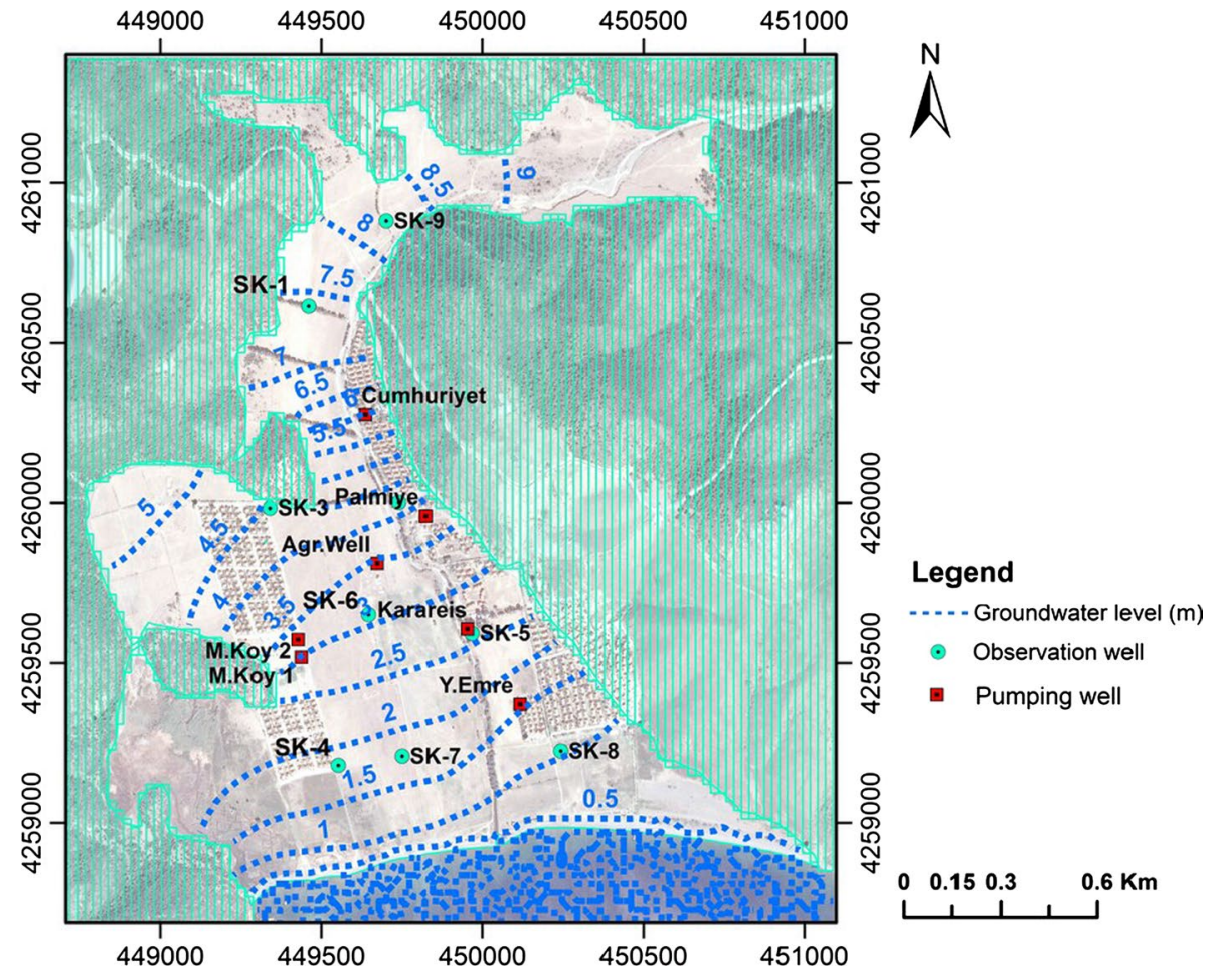




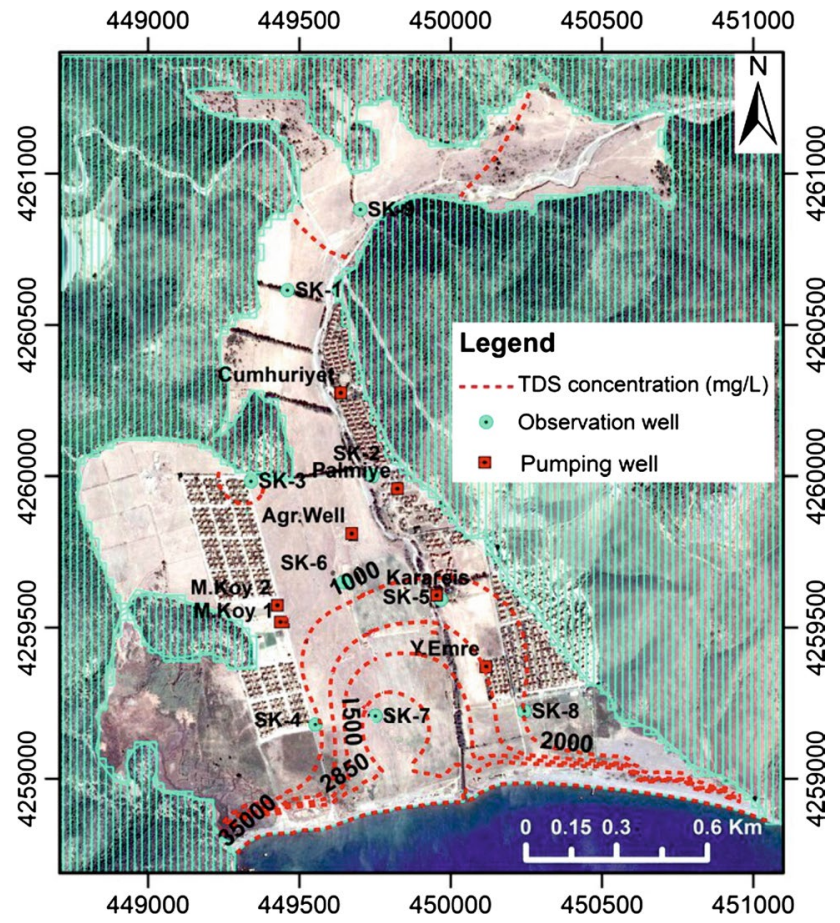

Fig. 8 Simulated TDS (mg/L) for the period (2014-2015) calculated by SEAWAT

The resulting groundwater levels under normal pumping conditions were compared against those obtained by the previously mentioned scenarios. Figure 9 shows the predicted groundwater levels of the first scenario at the end of 2024. It is clear from this map that if no extra pumping is allowed, groundwater levels are not expected to change at the end of the simulation period. Starting from the northern region of the study area toward the sea, the water level drops by $1-0.5 \mathrm{~m}$ in the second scenario. The result of the third scenario shows that the water level drops by $3 \mathrm{~m}$ at the end of the simulation period. In the fourth scenario, the water level drops below MSL in the central parts of the study area near to the newly drilled agricultural wells. This case may lead to reduction or reversal of fresh groundwater gradient, which would accelerate saline water intrusion. Finally, in the last scenario the water level is expected to drop by $1.5 \mathrm{~m}$ at the end of the simulation period.

Figures 9 also shows the comparison between the extents of seawater intrusion in the aquifer in year 2024 for all scenarios. In the first and fifth scenarios, the extents of the TDS concentration isolines in 2024 will be less than 2015 due to high infiltration and recharge from rainfall. Model results indicated that the seawater intrusion isoline (TDS concentration $=2000 \mathrm{mg} / \mathrm{L}$ ) will move about an additional $70 \mathrm{~m}$ landward in 2024. In the third scenario, this line will move about an additional $270 \mathrm{~m}$ landward in 2024. Finally, in the worst-case scenario it will move $420 \mathrm{~m}$ landward in 2024.
Thus, it can be concluded that increased groundwater withdrawal coupled with decreased recharge from precipitation will likely create significant declines in groundwater levels and further movement of salt-water interface inland. If the predicted trend in increased pumping continues in the next 10 years, the groundwater resources of Karareis aquifer will be significantly saline such that its domestic and agricultural use will be facing major drawbacks which can eventually create changes in socioeconomic status of the region.

The predictions performed by the scenarios reveal critical information with regards to salt water intrusion in the study area. Overall, it can be foreseen that it will be really hard to sustain fresh groundwater supply from the area given the fairly limited renewal potential of groundwater. The overall demand is going to increase under all possible scenarios. Unless fresh surface water supply alternatives are developed in the area, all demand will need to be supplied from the already stressed groundwater resources. Considering the fact that the alluvial aquifer of Karareis is the only viable groundwater reserve in the study area, additional demand will impose further burden on the aquifer. Efficient irrigation methods and wastewater reuse might be considered as possible options. In addition, distribution of groundwater extraction uniformly over the aquifer can also help with the increased intrusion rates from the already existing cone at the center of the aquifer.

Finally, the steady-state water balance was computed based on the available field data for the period 2014-2015. The model predicted total input $\left(721,382 \mathrm{~m}^{3} /\right.$ year $)$ and output $\left(720,680 \mathrm{~m}^{3} /\right.$ year) are approximately equal with less than $1 \%$ error. Water budget inflows included recharge from stream and precipitation $\left(721,382 \mathrm{~m}^{3} /\right.$ year $)$ while outflows included pumping for irrigation and domestic use $\left(109,683 \mathrm{~m}^{3} /\right.$ year) and discharge into the sea $\left(610,996 \mathrm{~m}^{3} /\right.$ year). The water budget of the Karareis region showed that most of the freshwater in the aquifer came from precipitation and discharged into the sea. Model results also showed that there was no major deficit ( $+702 \mathrm{~m}^{3} /$ year) in the water balance.

\section{Conclusions}

The purpose of this study is to assess the status of seawater intrusion in the coastal aquifer of Karareis region using numerical modeling. A 3-D variable-density groundwater flow model was developed to determine how far inland the seawater has already moved and will be expected to move in the future. The model input parameters were determined from analysis of geological logs and permeability tests. The SEAWAT code was used to solve the numerical model for the density-dependent flow system. The model was calibrated using PEST by adjusting the hydraulic 

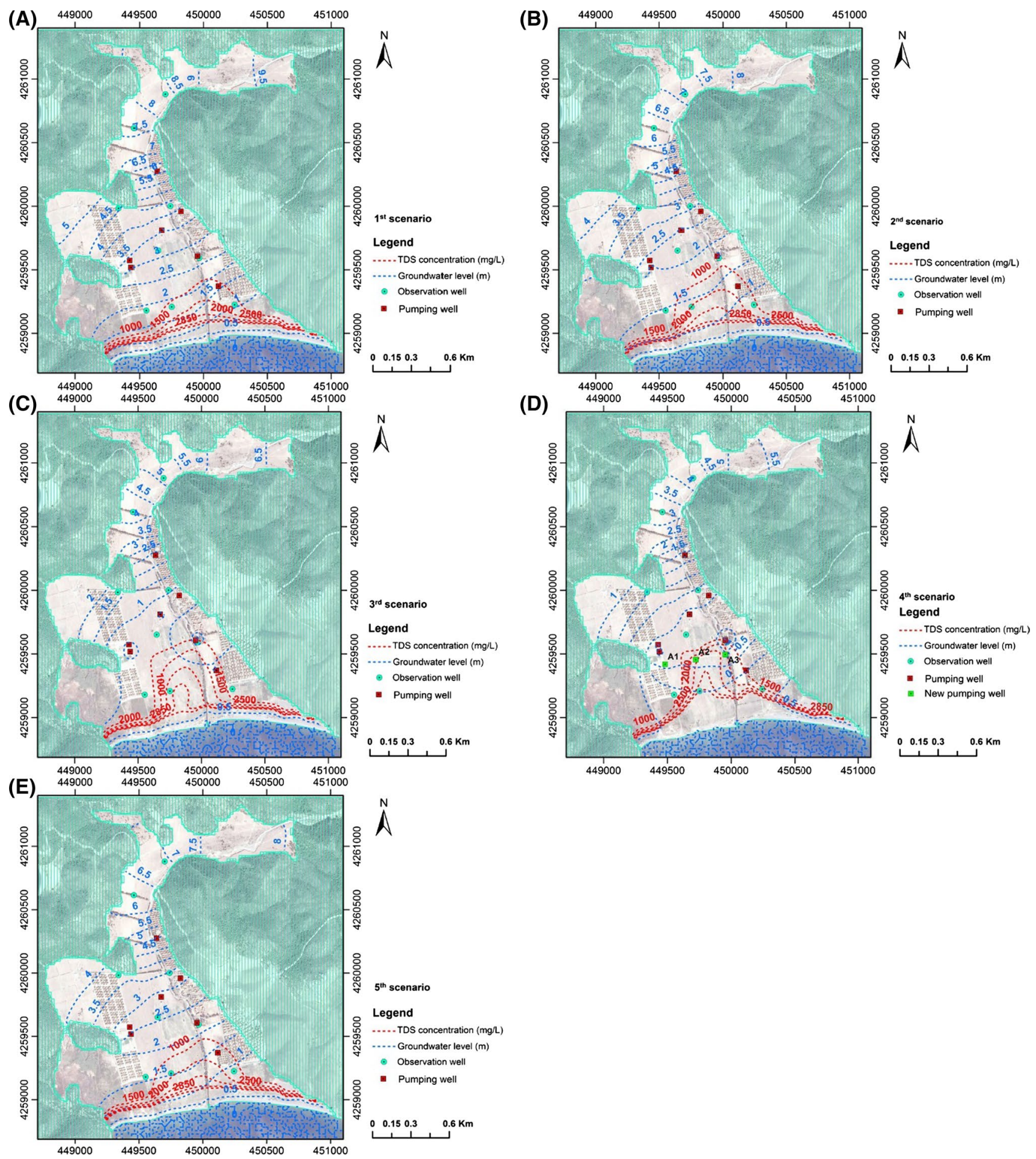

Fig. 9 Predicted contour lines of groundwater levels and TDS concentrations for the five scenarios in 2024, a first scenario, b second scenario, $\mathbf{c}$ third scenario, $\mathbf{d}$ fourth scenario, e fifth scenario

conductivities by minimizing the difference between the calculated and observed heads and TDS values. Following calibration, the model was validated by using another field observation dataset from a different time period and was shown to perform satisfactory. Once a reasonably good match was obtained between the observed and simulated levels for both calibration and validation periods, the model was later executed over the next 10 years 
(2014-2024) to evaluate the extent of seawater intrusion for five expected scenarios.

Based on model predictions, it was evident that the study area was affected from seawater intrusion. The pumping rate increase would lead to additional intrusion of seawater toward the populated area particularly during dry season when demand for groundwater was at its maximum. As a result, in the 10 years of increased pumping simulation, seawater intrusion will extend about $420 \mathrm{~m}$ inland. Based on the model results, it can be expected that the actual extent of seawater intrusion may be more severe than the model predictions since the used recharge rate was assumed to be equal to that of 2014-2015 conditions. In this regard, additional modeling needs to be conducted to use coupled recharge values based on real precipitation predictions coming from the predictions of climate change models. Additional model runs that utilize on-site precipitation measurements will certainly reveal more accurate results and will decrease the inaccuracies originating from using precipitation data of Karaburun meteorological station that is about $40 \mathrm{~km}$ away from the study area. The reliability of modeling results depends on the uncertainties in model parameters. Given that the conceptual model of the study area is accurate, modeling results can be also considered accurate when parameter uncertainties are small compared to the magnitude of the parameter value, and the fit between measured and simulated variable values is acceptable. Although an uncertainty analysis would give a quantitative evaluation of model uncertainty, without a thorough analysis uncertain model parameters can still be identified. For this study, some uncertainty exists in the precipitation observation (groundwater recharge) and the timing and magnitude of pumping rates. Uncertainties in both model parameters can be considered small due to the fact that both were based on actual measurement data. Uncertainties in other model parameters such as hydraulic conductivity, head and concentration measurements, etc., are directly related to measurement errors which can be considered as negligible when calibrated equipment is used. Therefore, changes predicted in the scenarios can be considered as significant that can ultimately lead to substantial changes in groundwater use of the region. Nevertheless, the reasonably good match between the observed and calculated values of groundwater levels and TDS concentrations reveals that the developed model provides a powerful management tool to make decisions regarding pumping schedules in the study area.

Finally, the results of this modeling study showed that the aquifer of Karareis region is very sensitive to increased pumping rates; therefore, appropriate management techniques should incorporate time-dependent maximum total pumping values that should not be exceeded in the study area.
Acknowledgements This study is funded by the Scientific and Technological Research Council of Turkey (TUBITTAK) through project number $113 \mathrm{Y} 042$.

\section{References}

Abd-Elhamid HF, Javadi AA (2011) A cost-effective method to control seawater intrusion in coastal aquifers. Water Resour Manag 25(11):2755-2780. https://doi.org/10.1007/s11269-011-9837-7

Allow KA (2011) Seawater intrusion in Syrian coastal aquifers, past, present and future, case study. Arab J Geosci 4(3):645-653. https://doi.org/10.1007/s12517-010-0261-8

Baba A, Simsek C, Solak O, Gunduz O, Elci A, Murathan A, Sozbilir $\mathrm{H}$ (2016) Investigation of sea water intrusion in coastal aquifiers: a case study from Karaburun Peninsula, Turkey. DSİ Tech Bull 120:14-24 (in Turkish)

Bakker M (2003) A Dupuit formulation for modeling seawater intrusion in regional aquifer systems. Water Resour Res 39(5):1131. https://doi.org/10.1029/2002WR001710

Bakker M, Essink GHO, Langevin CD (2004) The rotating movement of three immiscible fluids a benchmark problem. J Hydrol 287(1-4):270-278. https://doi.org/10.1016/j.jhydrol.2003.10.007

Bear J, Cheng AHD, Sorek S, Ouazar D, Herrera I (1999) Seawater intrusion in coastal aquifers: concepts, methods and practices. Springer, p 627. https://doi.org/10.1007/978-94-017-2969-7

Cobaner M, Yurtal R, Dogan A, Mortz LH (2012) Three dimensional simulation of seawater intrusion in coastal aquifers: a case study in the Goksu Deltaic Plain. J Hydrol 464:262-280. https://doi. org/10.1016/j.jhydrol.2012.07.022

Das BM (2013) Advanced soil mechanics, 4th edn. CRC Press, p 634. ISBN: 9780415506656

Dausman A, Langevin CD (2005) Movement of the saltwater interface in the surficial aquifer system in response to hydrologic stresses and water-management practices, Broward County, Florida, US Department of the Interior, US Geological Survey, Scientific Investigations Report 2004-5256, p 81

Felisa G, Ciriello V, Di Federico V (2013) Saltwater intrusion in coastal aquifers: a primary case study along the Adriatic Coast investigated within a probabilistic framework. Water 5:18301847. https://doi.org/10.3390/w5041830

Gaaloul N, Pliakas F, Kallioras A, Schuth C, Marinos P (2012) Simulation of seawater intrusion in coastal aquifers: forty five-years exploitation in an eastern coast aquifer in NE Tunisia. Open Hydrol J 6:31-44. https://doi.org/10.2174/1874378101206010031

Gopinath S, Srinivasamoorthy K, Saravanan K, Suma C, Prakash R, Senthilnathan D, Chandrasekaran N, Srinivas Y, Sarma V (2016) Modeling saline water intrusion in Nagapattinam coastal aquifers, Tamilnadu, India. Model Earth Syst Environ 2:2. https://doi. org/10.1007/s40808-015-0058-6

Guo W, Bennett G (1998) SEAWAT version 1.1 A computer program for simulations of ground water flow of variable density. A report prepared by Missimer International Inc. Fort Myers, FL

Jarvis A, Reuter HI, Nelson A, Guevara E (2008) Hole-filled SRTM for the globe Version 4. available from the CGIAR-CSI SRTM 90m Database (http://srtm.csi.cgiar.org)

Kallioras A, Pliakas F, Diamantis I (2006) Conceptual model of a coastal aquifer system in northern Greece and assessment of saline vulnerability due to seawater intrusion conditions. Environ Geol 51(3):349-361. https://doi.org/10.1007/s00254-006-0331-0

Karahanoglu N, Doyuran V (2003) Finite element simulation of seawater intrusion into a quarry-site coastal aquifer, Kocaeli-Darıca, Turkey. Environ Geol 44(4):456-466. https://doi.org/10.1007/ s00254-003-0780-7 
Kresic N (2007). Hydrogeology and groundwater modeling, 2nd edn. CRC Press, p 828. ISBN: 978-0849333484

Langevin CD (2003) Simulation of submarine ground water discharge to a marine estuary: Biscayne Bay, Florida. Ground Water 41(6):758-771. https://doi.org/10.1111/j.1745-6584.2003. tb02417.x

Langevin CD, Thorne DTJ, Dausman AM, Sukop MC, Guo W (2008) SEAWAT version 4: a computer program for simulation of multispecies solute and heat transport. U.S. Geological Survey Techniques and Methods Book 6, Chapter A22, Reston, VA

Lin J, Snodsmith JB, Zheng C, Wu J (2009) A modeling study of seawater intrusion in Alabama Gulf Coast, USA. Environ Geol 57(1):119-130. https://doi.org/10.1007/s00254-008-1288-y

Marinos V, Fortsakis P, Prountzopoulos G, Marinos P (2011) Permeability in flysch- distribution decrease with depth and grout curtains under dams. J Mt Sci 8(2):234-238

McDonald J, Harbaugh A (1988) MODFLOW, a modular 3D finite difference ground-water flow model. US Geological Survey. Open File Report: 83-875

Morris DA, Johnson AI (1967) Summary of hydrologic and physical properties of rock and soil materials, as analyzed by the hydrologic laboratory of the US Geological Survey, 1948-60, US Govt. Print. Off

Paniconi C, Khlaifi I, Lecca G, Giacomelli A, Tarhouni J (2001) A modelling study of seawater intrusion in the Korba coastal plain, Tunisia. Phys Chem Earth Part B 26(4):345-351. https://doi. org/10.1016/S1464-1909(01)00017-X

Qahman K, Larabi A (2006) Evaluation and numerical modeling of seawater intrusion in the Gaza aquifer (Palestine). Hydrogeol $\mathrm{J}$ 14(5):713-728. https://doi.org/10.1007/s10040-005-003-2

Sarsak R, Almasri MN (2013) Seawater intrusion into the coastal aquifer in the Gaza Strip: a computer-modelling study. Lancet 382:S32. https://doi.org/10.1016/S0140-6736(13)62604-5
Schneider JC, Kruse SE (2006) Assessing selected natural and anthropogenic impacts on freshwater lens morphology on small barrier Islands: Dog Island and St. George Island, Florida, USA. Hydrogeol J 14(1-2):131-145. https://doi.org/10.1007/ s10040-005-0442-9

Sherif M, Kacimov A, Javadi A, Ebraheem AA (2012) Modeling groundwater flow and seawater intrusion in the coastal aquifer of Wadi Ham, UAE. Water Resour Manag 26(3):751-774. https:// doi.org/10.1007/s11269-011-9943-6

Surinaidu L, Rao VVG, Mahesh J, Prasad PR, Rao GT, Sarma VS (2015) Assessment of possibility of saltwater intrusion in the central Godavari delta region, Southern India. Reg Environ Change 15(5):907-918. https://doi.org/10.1007/s10113-014-0678-9

Todd DK, Mays LW (2004) Groundwater hydrology, 3rd edn. Wiley, p 656, ISBN: 978-0-471-05937-0

Werner AD, Bakker M, Post VE, Vandenbohede A, Lu C, Ataie-Ashtiani B, Simmons CT, Barry DA (2013) Seawater intrusion processes, investigation and management: recent advances and future challenges. Adv Water Resour 51:3-26. https://doi.org/10.1016/j. advwatres.2012.03.004

Zheng C, Wang PP (1999) MT3DMS: a modular three-dimensional multispecies transport model for simulation of advection, dispersion, and chemical reactions of contaminants in groundwater systems; documentation and user's guide. Alabama University, Tuscaloosa, AL

Zimmermann S, Bauer P, Held R, Kinzelbach W, Walther JH (2006) Salt transport on islands in the Okavango Delta: numerical investigations. Adv Water Resour 29(1):11-29. https://doi.org/10.1016/j. advwatres.2005.04.013 